\title{
THE HIGH DOSE TOXICITY OF BETEL NUT (Areca catechu L.) ON REPRODUCTION ORGAN OF RATS
}

\author{
Ave Olivia Rahman, Herlambang, Charles A Simanjuntak, Hasna Dewi, Ahmad Syauqy,, \\ Lipinwati
}

Fakultas Kedokteran dan IImu Kesehatan Universitas Jambi

E-mail : aveoliviarahman@unja.ac.id

\begin{abstract}
Background : The use of long-term herbal medicines and high doses can damage organs, including the reproductive organs. Betel nut (Areca catechu L.) is one of the herbal ingredients that is consumed as a stamina enhancing beverage. The purpose of this study was to determine the effect of longterm treatment of raw betel nut at a dose of $10,000 \mathrm{mg} / \mathrm{kg}$ on testicular and ovary tissue of rats. Rats were Rattus norvegicus, Sprague Dawley strain, 2-3 months.

Methods : Tweenty rats divided into 2 groups, each groups were 5 male and 5 female. Control group was given aquades and the treatment group was given raw betel nut with a dose of 10,000 mg/kgBW for 45 days with a gastrictube. Histopathological examination with Haematoxylin-Eosin staining was used to assses testicular and ovary tissues.
\end{abstract}

Results: The ovaries of treatment groups had significantly lower de graff follicle compared to the control group $(p<0,05)$. The testis of treatment groups had significantly smaller diameter of tubulus seminifery, significantly higher necrosis of spermatogonia and spermatosit $(p<0,05)$.

Conclusion: Treatment of raw betel nut dose $10,000 \mathrm{mg} / \mathrm{kgBW}$ along 45 days causes damage of testicular and ovary tissues of rats.

Keywords: Betel Nut, Areca Catechu L., Histopathology, Testicular, Ovary, Herbal Toxicity

\section{ABSTRAK}

Latar Belakang: Pemakaian obat herbal jangka panjang dan dosis tinggi dapat menyebabkan kerusakan organ tubuh, termasuk organ reproduksi. Biji pinang (Areca catechu L.) merupakan salah satu bahan herbal yang dikonsumsi sebagai minuman penambah stamina.Tujuan penelitian ini adalah untuk mengetahui pengaruh pemberian biji pinang muda dosis $10.000 \mathrm{mg} / \mathrm{kgBB}$ selama 45 hari terhadap gambaran histopatologis testis dan ovarium tikus. 
Metode : Tikus yang digunakan adalah Rattus norvegicus galur Spague Dawley, usia 2-3 bulan, sebanyak 10 ekor jantan dan 10 ekor betina yang dibagi menjadi 2 kelompok, yaitu kelompok kontrol diberikan aquades dan kelompok perlakuan diberikan biji pinang dosis $10.000 \mathrm{mg} / \mathrm{kgBB}$ dengan sonde. Pemeriksaan histopatologi dengan pewarnaan Haematoxylin-Eosin untuk organ testis dan organ ovarium. Hasil: Jumlah folikel de draf pada kelompok perlakuan lebih sedikit dibandingkan kelompok kontrol $(p<0,05)$. Persentase nekrosis spermatogonia dan spermatosit pada kelompok perlakuan lebih tinggi dibandingkan kelompok kontrol $(p<0,05)$, diameter tubulus seminifeus pada kelompok perlakuan juga lebih kecil dibandingkan kelompok kontrol $(p<0,05)$.

Kesimpulan: Pemberian biji pinang $10.000 \mathrm{mg} / \mathrm{kgBB}$ selama 45 hari menyebabkan kerusakan pada jaringan testis dan ovarium pada tikus.

Kata Kunci : Biji Pinang, Areca Catechu L, Histopatologi, Ovarium, Testis, Toksisitas herbal

\section{PENDAHULUAN}

Pohon pinang banyak tumbuh di daerah Sumatra, khususnya Provinsi Jambi 1. Biji pinang telah dimanfaatkan sebagai obat sejak ribuan tahun sebelum masehi, terutama di Mesir dan India. Biji pinang juga masuk ke dalam daftar prioritas WHO (World Health Organization) ${ }^{2}$. Berdasarkan berbagai studi, biji pinang diketahui memiliki efek antibakteri, antioksidan, afrodisiak, dan antifertilitas. Di Jambi, pinang digunakan sebagai obat herbal dalam bentuk minuman jus pinang yang dipercayai oleh masyarakat sebagai penambah stamina dan meningkatkan libido.

Biji pinang mempunyai kandungan fitokimia antara lain polifenol dan alkaloid ${ }^{3}$. Arecoline adalah alkaloid utama pada biji pinang yang dianggap mempunyai efek sitotoksik pada berbagai sel mamalia. Selain manfaat yang telah disebutkan, biji pinang diduga mempunyai efek sitotoksik akibat kandungan arecolinenya terutama pada dosis tinggi. Toksisitas senyawa herbal pada organ reproduksi dapat menyebabkan infertilitas, sehingga beberapa senyawa herbal dapat digunakan sebagai obat kontrasepsi herbal ${ }^{4}$. Metode kontrasepsi dapat digunakan untuk mempengaruhi organ reproduksi baik pria dan wanita.

Penelitian ini bertujuan untuk mengetahui efek pemberian pinang muda dalam jangka panjang selama 45 hari terhadap gambaran histopatologi testis dan ovarium pada tikus.

\section{METODE PENELITIAN}

Penelitian ini telah mendapat persetujuan etik dari komisi etik FKIK Unja. Penelitian dilakukan di Laboratorium Biomedik Fakultas Kedokteran dan IImu Kesehatan Universitas Jambi dalam rentang waktu bulan September 2017 sampai bulan Oktober 2018.

Sediaan pinang muda dibuat baru setiap hari. Biji pinang yang digunakan adalah biji pinang yang berkulit hijau. Biji pinang ditimbang kemudian dihaluskan dan 
ditambahkan aquades sesuai perhitungan dosis yang digunakan, yaitu $10.000 \mathrm{mg} /$ kgBB. Pinang diberikan dengan menggunakan sonde.

Tikus yang digunakan adalah Rattus norvegicus dewasa galur Sprague Dawley umur 2-3 bulan, jantan dan betina, berat badan 150-200 gram. Tikus dibagi dalam 2 kelompok yaitu kelompok perlakuan yang diberikan pinang dan kelompok kontrol yang diberikan aquades. Setiap kelompok terdiri dari 5 ekor jantan dan 5 ekor betina. Sebelum perlakuan, tikus diaklimatisasi selama 1 minggu. Tikus dipelihara pada kandang dengan suhu, kelembaban, cahaya yang cukup. Makan dan minum diberikan secara ad libitum. Perlakuan diberikan setiap hari selama 45 hari. Pada hari ke-46, tikus diterminasi dan dilakukan pengambilan organ testis dan ovarium untuk selanjutnya disimpan dalam formalin $10 \%$.

Pemeriksaan histopatologi dengan pewarnaan Haematoxylin-Eosin. Penilaian jaringan testis meliputi diameter tubulus seminiferus, nekrosis pada spermatogonia, spermatosit dan spermatozoa. Pengukuran diameter tubulus seminiferus menggunakan micrometer pada dengan pembesaran 100x, diukur pada diameter terpendek sebanyak 4 lapangan pandang, 5 tubulus tiap lapangan pandang. Penilaian persentase nekrosis dilakukan dalam 5 tubulus semineferus pada dengan pembesaran 400x dengan skoring semikualitatif yaitu tidak ada (skor 1 ), $<30 \%$ (skor 2), $30-50 \%$ (skor 3 ) dan $>50 \%$ (skor 4).Penilaian jaringan ovarium meliputi jumlah folikel primer, folikel sekunder, folikel tersier, folikel de graff, korpus luteum, dan folikel kistik. Pembacaan preparat menggunakan mikroskop cahaya yang dilakukan oleh ahli patologi anatomi.

Data akan disajikan dalam bentuk rerata \pm simpang baku. $U \mathrm{ji}$ beda menggunakan uji T-Independent untuk distribusi data normal atau uji Mann-Whitney untuk distribusi tidak normal dengan tingkat kepercayaan $p<0,05$.

\section{HASIL DAN PEMBAHASAN}

Perbandingan hasil pemeriksaan histopatologi jaringan testis kelompok perlakuan dan kelompok kontrol dapat dilihat pada tabel 1. Kelompok perlakuan mempunyai rerata diameter tubulus seminiferus lebih kecil dibandingkan kelompok kontrol dan perbedaan tersebut bermakna secara statistika $(p<0,05)$. Persentase nekrosis sel spermatogonia, sel spermatosit, sel spermatid dan sel spermatozoa pada kelompok perlakuan lebih tinggi dibandingkan kelompok kontrol, dimana perbedaan tersebut bermakna untuk nekrosis sel spermatogonia dan sel spermatosit $(p<0,05)$.

Perbandingan hasil pemeriksaan histopatologi jaringan ovarium kelompok perlakuan dan kelompok kontrol dapat dilihat pada tabel 2. Rerata jumlah folikel primer, folikel sekunder, folikel de graf dan korpus luteum ovarium pada kelompok perlakuan lebih kecil dibandingkan dengan kelompok kontrol. Perbedaan tersebut bermakna untuk folikel primer dan folikel degraf $(p<0,05)$. Sedangkan untuk folikel tersier, kelompok perlakuan mempunyai rerata jumlah lebih tinggi dibandingkan kelompok kontrol, akan tetapi perbedaan tersebut tidak bermakna $(p>0,05)$. Rerata 
jumlah folikel kistik pada kelompok

perlakuan lebih rendah dibandingkan

kelompok kontrol $(p>0,05)$.

Tabel 1. Perbandingan hasil histopatologi jaringan testis antara kelompok perlakuan dengan kelompok kontrol

\begin{tabular}{llll}
\hline Parameter & Kelompok kontrol & Kelompok perlakuan & Nilai p \\
\hline Diameter tubulus seminiferus & $28,49 \pm 0,31 \mu \mathrm{m}$ & $21,09 \pm 0,13 \mu \mathrm{m}$ & $0,008^{*}$ \\
Nekrosis spermatogonia & 1,00 & $3,4 \pm 0,54$ & $0,008^{*}$ \\
Nekrosis spermatosit & $1,40 \pm 0,54$ & 3,00 & $0,008^{*}$ \\
Nekrosis spermatid & $1,40 \pm 0,54$ & 2,00 & 0,151 \\
Nekrosis spermatozoa & $2,40 \pm 0,54$ & 3,00 & 0,151 \\
\hline
\end{tabular}

Uji Mann Whitney, * nilai p bermakna

Tabel 2. Perbandingan hasil histopatologi jaringan ovarium antara kelompok perlakuan dengan kelompok kontrol

\begin{tabular}{llll}
\hline Parameter & Kelompok kontrol & Kelompok perlakuan & Nilai p \\
\hline Folikel primer & $3,2 \pm 1,8$ & $1 \pm 0,7$ & $0,034^{*}$ \\
Folikel sekunder & $5,4 \pm 1,7$ & $3,0 \pm 2,0$ & 0,074 \\
Folikel tersier & $1 \pm 1,7$ & $1,2 \pm 0,8$ & 0,822 \\
Folikel de graff & $0,6 \pm 0,5$ & 0,0 & $0,040^{*}$ \\
Korpus luteum & $8 \pm 4,5$ & $5,2 \pm 1,2$ & 0,216 \\
Folikel kistik & $1,4 \pm 0,9$ & $0,6 \pm 0,5$ & 0,126
\end{tabular}

Uji T-Independent, * nilai p bermakna

Gambaran hasil pemeriksaan histopatologi jaringan testis dapat dilihat pada gambar 1 dan jaringan ovarium pada gambar 2. 

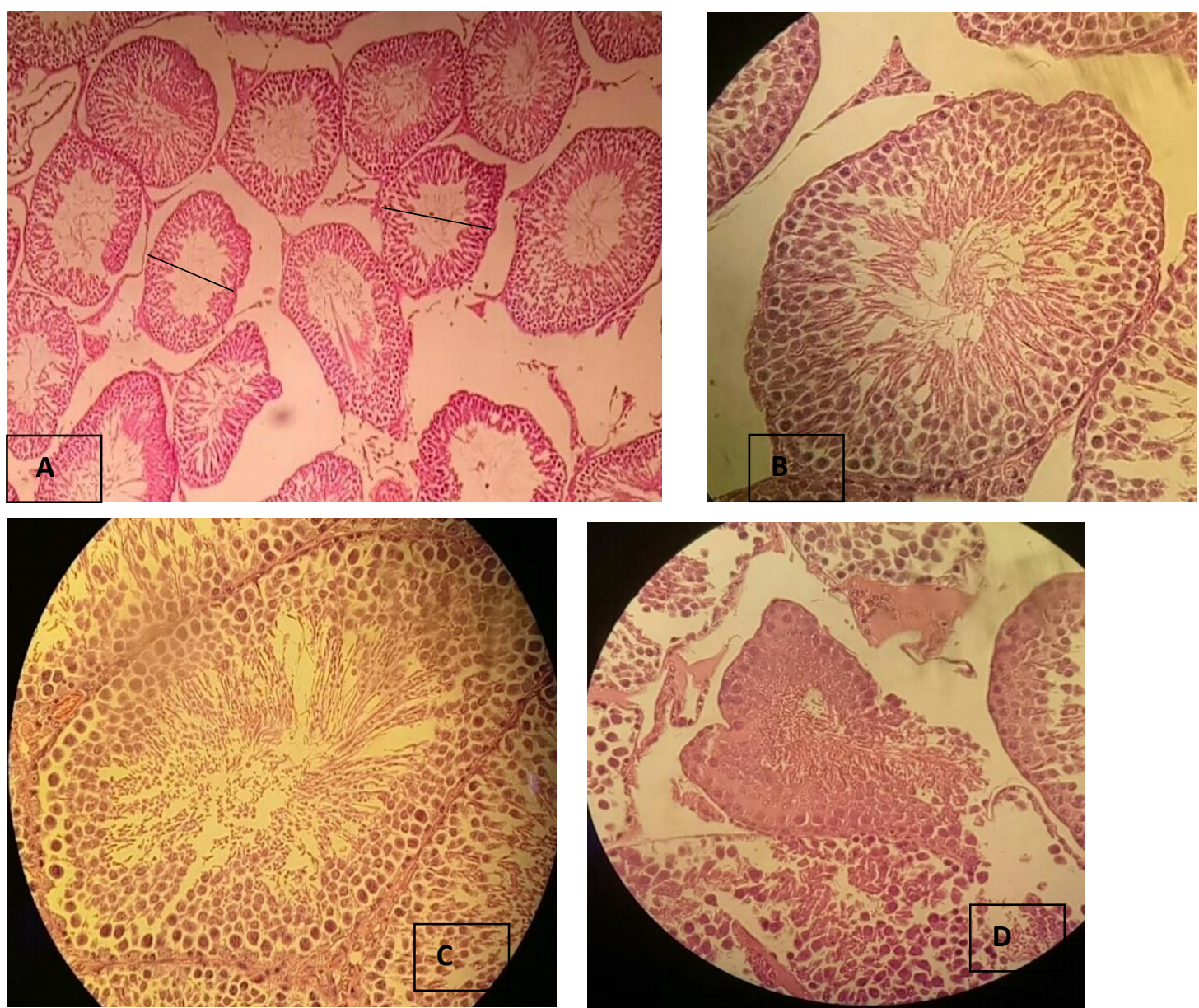

Gambar 1. Gambaran mikroskopis jaringan testis. (A) Tampak tubulus seminiferus dengan pembesaran 100x (garis adalah diameter terpendek yang digunakan dalam pengukuran), (B) Tampak tubulus seminiferus kelompok kontrol dengan pembesaran 400x, sel tersusun disekeliling tubulus dari luar ke dalam berurutan adalah spermatogonia, spermatosit, spermatid dan spermatozoa. (C, D) Tampak tubulus seminiferus kelompok perlakuan dengan pembesaran 400x, sel tersusun disekeliling tubulus dari luar ke dalam berurutan adalah spermatogonia, spermatosit, spermatid dan spermatozoa, tampak nekrosis lebih banyak dibandingkan kelompok kontrol.

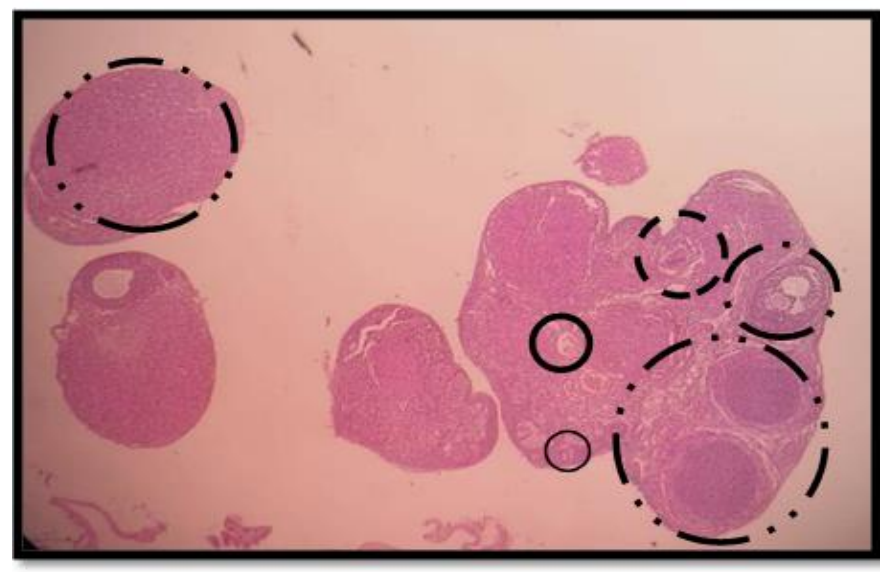

Gambar 2. Gambaran mikroskopis jaringan ovarium. Mikroskopis Ovarium Tikus pada kelompok Kontrol dengan pembesaran 100x. Folikel primer berukuran paling kecil ditandai dengan satu lapis sel granulosa. Folikel sekunder merupakan tahapan lanjut dari folikel primer. Folikel tersier ditandai dengan adanya celah yang terisi dengan cairan folikuler di kedua sisi luar oosit (antrum). Folikel de graff ditandai dengan adanya celah folikuler yang jauh lebih besar dari folikel tersier dan terdapat oosit matang pada bagian tepi folikel 
yang dihubungkan dengan beberapa sel granulosa yang mengelilingi ovum yang semakin sedikit. Folikel kistik terbentuk ketika folikel ovarium tidak melepaskan sel telur, kemudian tumbuh menjadi kista. Korpus luteum merupakan ruang folikuler yang terisi dengan darah dan cairan limpa setelah terjadinya ovulasi, berukuran besar.

Keterangan:

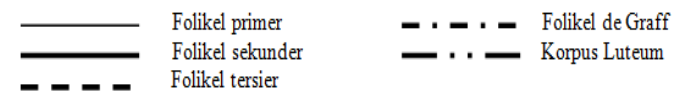

\section{Efek Biji Pinang terhadap Jaringan Testis Tikus}

Proses perkembangan spermatozoa (spermatogenesis) terjadi didalam tubulus seminiferus. $\mathrm{Di}$ dalam lapisan tubulus seminiferus terdapat sel-sel germinal dan sel-sel sertoli yang berperan dalam spermatogenesis. Proses spermatogenesis dimulai dari lapisan terluar tubulus seminiferus menuju lapisan yang lebih dalam dan akhirnya mencapai lumen dimana sel spermatozoa matur dilepaskan. Proses spermatogenesis sangat penting dalam menghasilkan fungsi reproduksi prian yang normal ${ }^{5}$.

Pada penelitian ini, persentase nekrosis selsel germinal (spermatogonia, spermatosit, spermatid dan spermatozoa) pada kelompok perlakuan lebih tinggi dibandingkan kelompok kontrol. Rerata diameter tubulus seminiferus pada kelompok perlakuan lebih rendah dibandingkan kelompok kontrol $(p<0,05)$. Rendahnya ukuran diameter tubulus seminiferus sejalan dengan tingginya kerusakan sel germinal yang terdapat di lapisan dinding tubulus seminiferus. Hal ini menunjukkan bahwa pemberian pinang pada penelitian ini dapat menyebabkan kerusakan sel germinal pada tubulus seminiferus tikus.

Hasil penelitian ini sesuai dengan penelitian lain yang menyebutkan bahwa pemberian pinang dosis tinggi ataupun arecoline yang merupakan kandungan alkaloid utama dalam pinang, dapat menyebabkan kerusakan sperma secara kualitas dan kuantitas ${ }^{6-11}$. Studi oleh Muslim Akmal tahun 2007, pemberian ekstrak etanolik biji buah pinang dosis 2 gram/200gramBB selama 7 hari menyebabkan kerusakan akut jaringan testis dan penurunan motilitas sperma, sedangkan pada dosis 1 gram/200gramBB tidak menunjukkan kerusakan secara signifikan ${ }^{9}$.

\section{Efek Biji Pinang terhadap Jaringan Ovarium Tikus}

Folikel primer, folikel sekunder, folikel tersier dan folikel de graf merupakan merupakan tahap perkembangan dan pematangan folikel ovarium (follikulogenesis) pada mamalia, termasuk tikus dan manusia. Folikel de graff merupakan tahap folikulogenesis dimana siap untuk melepaskan oosit (ovulasi) dan akan berubah menjadi korpus luteum setelah ovulasi. Proses folikulogenesis ovarium sangat penting untuk menghasilkan fungsi reproduksi wanita yang normal. Perubahan folikulogenesis dapat menyebabkan perubahan jumlah folikel ${ }^{12}$.

Pada penelitian ini, jumlah folikel de graf pada kelompok perlakuan lebih sedikit dibandingkan kelompok kontrol dan perbedaan ini bermakna $(p<0,05)$. 
Begitupula dengan korpus luteum, jumlah korpus luteum pada kelompok perlakuan lebih rendah dibandingkan dengan kelompok kontrol. Hal ini menunjukkan bahwa pinang menyebabkan gangguan pematangan folikel. Hasil penelitian lain juga menunjukkan bahwa pemberian ekstrak pinang $300 \mathrm{mg} / \mathrm{kgBB}$ dapat menyebabkan efek antiovulatori, dengan gambaran histopatologi ovarium menunjukkan jumlah folikel degraf dan korpus luteum lebih sedikit dibandingkan kontrol 13,14. Pada studi in vitro menggunakan kultur sel ovarium chinese hamster, ekstrak air biji pinang menyebabkan peningkatan apoptosis sel ovarium ${ }^{15}$.

\section{Mekanisme Biji Pinang Menginduksi Kerusakan Organ Reproduksi}

Biji pinang mengandung sejumlah senyawa alkaloid. Arecoline merupakan alkaloid utama yang terkandung dalam biji pinang. Arecoline diketahui bersifat mutagenik dan sitotoksik pada hampir semua jaringan 11,1619. Stress oksidatif merupakan mekanisme utama dalam kematian sel, regulasi den dan proses inflamasi yang diinduksi oleh arecoline $8,20,21$. Penelitian lain menyebutkan bahwa areca catechu meningkatkan proses apoptosis ${ }^{15,22}$, menghentikan siklus sel ${ }^{23}$. Pada penelitian ini hanya melihat gambaran ada tidaknya perubahan jaringan testis dan ovarium melalui pemeriksaan histopatologis dengan pewarnaan Haematoxylin Eosin, sehingga tidak dapat menjelaskan mengenai mekanisme kerusakan yang terjadi. Penelitian lebih lanjut diperlukan untuk mengetahui mekanisme kerusakan sel testis dan ovarium akibat biji pinang muda.

\section{KESIMPULAN DAN SARAN}

Pemberian jus biji pinang dosis
$10.000 \mathrm{mg} / \mathrm{kgBB}$ selama 45 hari menyebabkan kerusakan jaringan testis dan jaringan ovarium pada tikus. Penelitian lebih lanjut mengenai mekanisme kerusakan jaringan testis dan ovarium perlu dilakukan.

\section{DAFTAR PUSTAKA}

1. Puslitbang Perkebunan. Teknologi Budidaya dan Pasca Panen Pinang. Bogor; 2015.

2. World Health Organization. Prevention and Control of Areca (Betel) Nut and Tobacco Use. World Health Organization; 2018.

3. Amudhan MS, Begum VH, Hebbar KB. A Review on Phytochemical and Pharmacological Potential of Arecha Catechu L. Seed. Int J Pharm Sci Res. 2012;3(11):4151-7.

4. Umadevi M, Kumar PKS, Bhowmik D, Duraivel S. Medicinal oPlants with Potential Antifertility Activity. Journal of Medicinal Plants Studies. 2013;1(1):26-33.

5. Creasy DM, Chapin RE. Male Reproductive System in Hascheck and Rousseaux's Handbook of Toxicology $3^{\text {rd }}$ Edition :. Elsivier : 2013. 2501-2513.

6. Mukherjee A, Chakrabarti J, Chakrabarti A, Banerjee T, Sarma A. Effect of ' Pan Masala' on the germ cells of male mice. Cancer Letters. $1991 ; 58: 161-5$. 
7. Kumar S, Nigam SK, Shaikh SA, Saiyed HN. Effect of Pan Masala on Sperm Morphology of a Mouse. Bull, Environ, Contam, Toxicol. 2003;70:1184-8.

8. Akmal M, Am A, W dan Riawan W. Ekspresi Cyclooxygenase-2 (COX-2) pada Jaringan Testis Tikus (Rattus norvegicus) Akibat Paparan Ekstrak Biji Pinang (Areca catechu). J Kedokt brawijaya. 2007;23(3):121-4.

9. Am A, Akmal M, Rosmaidar. Efek Antifertilitas Fraksi Air Biji Pinang ( Areca catechu ) sebagai Agen Apoptosis pada Sel-sel Jaringan Testis Rattus norvegicus. Media Kedokteran Hewan. 2007; 23(3):179-83.

10. Kuo T, Luo S, Chiang S, Lee C, Liu Y, Chang J, et al. Arecoline Induces TNF-alpha Production and Zonula Occludens-1 Redistribution in Mouse Sertoli TM4 cells.Journal of Biomedical Science. 2014; $21(93): 1-10$.

11. Zhou J, Sun Q, Yang Z, Zhang J. The Hepatotoxicity and Testicular Toxicity Induced by Arecoline in Mice and Protective Effects of Vitamins C and E. Korean J Physiol Pharmacol. 2014;18(2):1438.

12. Rudmann DG, Foley GL. Female Reproductive System in Haschek and Rousseaux's Handbook of Toxicologic Pathology Third Edition.. Elsevier; 2013. 2603-2610.

13. Shrestha J, Shanbhag T, Shenoy S, Amuthan A, Prabhu K, Sharma S et al. Antiovulatory and abortifacient effects of Areca catechu (betel nut) in female rats. Indian Journal of Pharmacology. 2010; 42(5):306-311.

14. Islam AFMS, Rahman MS, Chowdhury SAR, Alam T, Khan MI. Inhibition of Ovarian Compensatory Hypertrophy by Arecholine in Adult female mice. Bangladesh Medical Journal. 1993.

15. Lin C, Chang M, Chang H, Wang T, Tseng W, Tai T, et al. Research Article Areca Nut-Induced Micronuclei and Cytokinesis Failure in Chinese Hamster Ovary Cells is Related to Reactive Oxygen Species Production and Actin Filament Deregulation. Environmental and Molecular Mutagenesis. 2009; 50: 367-74.

16. Wei X, Zhang J, Niu J, Zhou X, Li J, Li B. Evaluation of Arecoline Hydrobromide Toxicity After A 14-Day Repeated Oral Administration in Wistar Rats. PLoS One. 2015;10(4):1-23.

17. Chou WW, Guh JY, Tsai JF, Hwang CC, Chen HC, Huang JS et al. Arecoline-Induced Growth Arrest and P21WAF1 Expression are Dependent on P53 in Rat Hepatocytes. Toxicology. 2008;243(1-2):1-10.

18. Lin K, Lin C, Liu C, Chou M, Lin J. Arecoline N -Oxide: Its Mutagenicity and Possible Role as Ultimate Carcinogen in Areca Oral Carcinogenesis. Journal of Agricultural and food chemistry. 2011;59: 3420-8.

19. Chiang $S$, Jiang $S$, Wang $Y$, Chiang $H$, Chen $P$, Tu H, et al. Characterization of Arecoline-Induced Effects on Cytotoxicity in Normal Human Gingival Fibroblasts by Global Gene Expression Profiling. Toxicological Sciences. 2007;100(1):66-74.

20. Lai K, Lee T. Genetic Damage in Cultured Human Keratinocytes Stressed by Long-Term Exposure To Areca Nut Extracts. Mutation Research. 2006;599:66-75.

21. Thangjam GS, Kondaiah P. Regulation of Oxidative- Stress Responsive Genes by Arecoline in Human Keratinocytes. J Periodont Res. 2009;(1):673-82.

22. Yen C, Liu S, Lin M, Liu Y. Areca Nut Contains Both Apoptosis- and Autophagy-Inducing Ingredients and Its Possible Effects on Cancer Cells. Journal of Biomedical Sciences. 2016; 5(1:7): 3-7. 
23. Chang MC, Ho YS, Lee PH, Chan CP, Lee JJ, Hahn LJ, et al. Areca Nut Extract And Arecoline Induced The Cell Cycle Arrest But Not Apoptosis Of Cultured Oral KB Epithelial Cells:

Association Of Glutathione, Reactive Oxygen Species And Mitochondrial Membrane

Potential.Carcinogenesis. 2001;22(9):1527-35. 